\title{
Miscanthus: Genetic Diversity and Genotype Identification Using ISSR and RAPD Markers
}

\author{
Sandra Cichorz $\cdot$ Maria Gośka $\cdot$ Anna Litwiniec
}

Published online: 1 June 2014

(c) The Author(s) 2014. This article is published with open access at Springerlink.com

\begin{abstract}
Due to the limited number of molecular studies focused on European gene pool investigation, it is necessary to perform plant material recognition. Eighteen accessions of three Miscanthus species, namely, $M . \times g i$ ganteus, M. sinensis, M. sacchariflorus were evaluated with the use of molecular marker systems such as: inter simple sequence repeats (ISSRs), random amplified polymorphic DNA (RAPD), and by estimation of ploidy level based on flow cytometry. As a result, only one ISSR primer (ISSR1) and three RAPD primers (RAPD1, RAPD2, RAPD4) were required to identify all genotypes. Moreover, the use of the above mentioned molecular markers enable the proper species recognition of the interspecific hybrid M. $\times$ giganteus "Floridulus," which has been previously mislabeled as $M$. floridulus. The highest genetic similarity coefficient (0.94) was observed between $M . \times$ giganteus clones, which indicates that the genetic diversity within this species was very low. Whereas $M$. sinensis genotypes represented a relatively wide diversity with similarity coefficient of 0.58 . Cluster analysis using UPGMA grouped the 18 accessions in three clusters according to species affiliation including relabeled $M . \times$ giganteus "Floridulus," which proved to be closely related to
\end{abstract}

\footnotetext{
S. Cichorz $(\bowtie) \cdot$ M. Gośka $\cdot$ A. Litwiniec

Research Division in Bydgoszcz, Department of Genetics and Breeding of Root Crops, Plant Breeding and Acclimatization Institute - National Research Institute, Powstańców Wielkopolskich 10, 85-090 Bydgoszcz, Poland

e-mail: s.cichorz@ihar.bydgoszcz.pl

M. Gośka

e-mail: m.goska@ihar.bydgoszcz.pl

A. Litwiniec

e-mail: a.litwiniec@ihar.bydgoszcz.pl
}

M. $\times$ giganteus. Similar groupings were evident in the PCoA analysis.

Keywords Miscanthus - Genetic diversity $\cdot$ Molecular markers - Identification of ecotypes and varieties · Flow cytometry $\cdot$ Ploidy level

\section{Introduction}

Nowadays, due to limited fossil fuels resources and their increasing detrimental effects on the global climate, the biomass production is of particular interest as a renewable source of energy. The main favorable traits of potential bioenergy crop species refer to efficient conversion of free solar power into harvestable biomass with minimal inputs to the environment [1]. Because of a high yield and low environmental requirements, energy grasses such as $\mathrm{Mi}$ scanthus are important crops for biomass production [2]. Vast number of field experiments from distinct regions of Europe demonstrate that Miscanthus can achieve the higher energy production in comparison with other energy plants such as annual food crops and woody short rotation coppice species [1, 3, 4] or even distinct perennial grass species [5]. Considering the $\mathrm{C} 4$ photosynthesis pathway in these plants, the carbon fixation achieves high rates. The use of nutrients, water so as solar radiation is more efficient in comparison with other plants. All those physiological properties influence adaptation to varied soil and climate conditions. The fact that these grasses are rhizomatous, perennial crops have also a good influence on the lower use of fertilizers required to receive satisfactory biomass yield [6].

The genus Miscanthus Anderss. of the Poaceae family [7] includes approximately 12 species among which the most valuable species for biomass production are 
M. sacchariflorus, M. sinensis, M. $\times$ giganteus, and $M$. floridulus [6]. In Europe, the cultivation of Miscanthus is mainly based on $M . \times$ giganteus of tropical and subtropical origin [8, 9]. The $M . \times$ giganteus $(2 n=3 \times=57)$ is an interspecific hybrid between the diploid $M$. sinensis $(2 n=2 \times=38)$ and the allotetraploid $M$. sacchariflorus $(2 n=4 \times=76)$ [10-12]. The efficient biomass productivity of the resulting triploid is caused by a heterosis effect that commonly arises in hybrid cultivars [13]. As a consequence of seed sterility $M . \times$ giganteus is reproduced only vegetatively by rhizome cuttings or in vitro cultures $[14,15]$, which limits the risk of its release from a cultivation ecosystem to the natural environment [16], but at the same time leads to display very limited genetic diversity. Ideally, there are two or three closely related clones in cultivation [17], but there is a huge probability that European Miscanthus wide biomass production is based on one clone [9]. Similar situation is observed in North America, where $M . \times$ giganteus legacy cultivars are expected to be derived via vegetative propagation from a single genet of European origin [18, 19]. Greef et al. [13], using AFLP technique, sampled 31 accessions of $M . \times$ giganteus, 11 clones of $M$. sinensis and two clones of $M$. sacchariflorus that are advisable for cultivation in botanic and market gardens of Middle Europe. From the main $M . \times$ giganteus pool, which indicated low genetic diversity, only three accessions differed, while $M$. sinensis pool showed relatively wide diversity. During similar comparison, Hodkinson et al. [17] also employed AFLP and ISSR markers to characterize genetic resources of 75 accessions from collections at RBG Kew and ADAS Arthur Rickwood Research Station, UK. For the M. × giganteus accessions (11 taxa), no variation was detected with the use of ISSR markers and little variation most probably due to scoring error with the use of AFLP markers, in contrast to $M$. sinensis accessions (50 taxa) with evident and high level of variation. In another study, De Cesare et al. [20] confirmed that 14 out of $15 \mathrm{M} . \times$ giganteus accessions collected from TCD Botanic Gardens, Dublin, Ireland and University of Hohenheim, Germany that were analyzed with six cpSSR marker loci shared the same haplotype, whereas $M$. sinensis and $M$. sacchariflorus indicated a high level of polymorphism for certain alleles. As mentioned by $\mathrm{Ma}$ et al. [21] M. sinensis represents highly heterozygous genome. During recent studies performed by the above mentioned research group, with the use of genotyping by sequencing (GBS) the composite linkage map composed of 3,745 SNP markers spanning 2,396 cM on 19 linkage groups was revealed. Moreover, the results indicated that diploid M. sinensis is tetraploid origin consisting of two sub-genomes. It showed that sorghum has the closest synthetic relationship to Miscanthus in comparison with maize, rice and Brachypodium distachyon. Unfortunately, in accordance with literature the designation and distribution of primary particular clones belonging to $M$. $\times g i$ ganteus species among either Europe or the USA is dubious and conjectural. The unquestionable fact is that the first $M . \times$ giganteus clone was imported from Japan to Denmark in 1935 by a nursery man, Aksel Olsen as an ornamental plant, and later to North America by commercial clonal propagation [10]. Sacks et al. [22] proposed the above mentioned genotype of $M . \times$ giganteus, which is widespread and predominantly cultivated in Europe and the USA, to be popularly called as "Aksel Olsen," so as Zub and Brancourt-Hulmel [9]. Taking into consideration the above mentioned facts and the description of Miscanthus genotype made by Clifton-Brown and Lewandowski [23] there is a huge probability that "Aksel Olsen" is the spare designation of "Clone Hornum" after the Danish Institute for Landscape Plants at Hornum, where biomass trials with this clone began. According to Sacks et al. [22] later on Deuter and Abraham [24] reported the second clone called M. × giganteus "Harvey," which previously existed in Japan and was imported to England about 1980s. Consequently, the origin of different clones could be explained by a distinct natural hybridization event, which occurred in Asia and distributed to Europe. In some collections e.g., The Royal Botanic Garden, Kew and ADAS Arthur Rickwood Research Station M. × giganteus "Harvey" was incorrectly labeled as $M$. sacchariflorus or $M$. sinensis "Giganteus" and only AFLP analysis revealed the proper taxonomy of this accession [12, 17].

Moreover, in the USA, the most prevalent clone available in the public domain is designed "Illinois" and propagated from a plant growing at the Chicago Botanic Gardens [25], which was originally received from Europe and was of the same genetic identity as the $M . \times$ giganteus genotype widely propagated in Great Britain [26]. This indicated that a narrow gene pool of $M . \times$ giganteus existed. It should be emphasized that cultivation based on genetically uniform unimproved clones is inadequate on the grounds of: disease risk, overwintering problems during the first vegetative season, relatively expensive establishment or varying plant quality requirements for different uses [8, 17, 26, 27]. On account of the above mentioned facts, a crucial factor in Miscanthus crop improvement programs is the collection and utilization of diverse germplasms [26].

Unfortunately, little effort has been undertaken to accurately identify cultivars that are available within the germplasm collections of that genus. During the same characterization of a resource collection, Greef et al. [13] indicated, based on AFLP technique, that many of the sampled accessions were inadequately classified as $M$. sacchariflorus instead of $M . \times$ giganteus or M. sinensis, whereas Hodkinson et al. [17] accurately assessed 12 
cultivars of Miscanthus using AFLP accompanied by morphological data. It shows that $16 \%$ of the analyzed accessions were previously unnamed or mislabeled based only on morphological observations.

For the above mentioned reasons, proper choice of the plant material is relevant during cultivation at large areas. As described in a review by Heaton et al. [26] recent efforts of breeding programmes are focused on collection and export of Miscanthus germplasms from countries in Southeast Asia. But it requires arrangement of formal partnerships. Furthermore, seeds or propagules must be tested and inspected by a government-approved plant pathologist before release. The current challenge is to screen existing germplasm collections and broaden the genetic base of $M . \times$ giganteus by creating hybrids from wild parents: $M$. sinensis and $M$. sacchariflorus [6]. In view of a relatively high genetic diversity of the parental components as compared with $M . \times$ giganteus, valuable traits could be bred into new varieties [13, 20, 28].

Due to these facts, the estimation of genetic diversity is a prerequisite for the conservation and utilization in breeding programmes [29]. Over the past decade reports in the literature indicate the effective application of molecular markers, based on DNA fingerprinting, used in the studies of Miscanthus species. There are potentially many techniques to choose from, such as: RFLP [11], the above mentioned AFLP [12, 13, 17] or SSR [29]. Among these, random amplified polymorphic DNA (RAPD) [30, 31] and inter simple sequence repeats (ISSR) [32] are rapid and inexpensive methods with no requirements of probes or sequence information. They have been widely used in genetic map construction [33] or diversity analysis of $\mathbf{M i}$ scanthus resources collections held in Europe [17] and the naturally occurring populations [34-36].

Due to the lack of information concerning species identification and characterization of genetic diversity among Miscanthus genus available in Poland and limited number of studies focused on the European gene pool, it is necessary to optimize a precise method for plant material recognition. It should be underlined that Poland, so as France and Germany [3], is a promising bioenergy producing region, especially for Miscanthus. Moreover, in comparison with Hungary, United Kingdom, Italy and Lithuania in Poland the production, storage and transportation costs are relatively low [2].

The purpose of this research was to genetically evaluate 18 accessions of Miscanthus species belonging to the Plant Breeding and Acclimatization Institute - National Research Institute (PBAI - NRI, Research Division in Bydgoszcz, Poland) collection with the use of molecular and cytological observations and select a subset of genotypes that represent the vast majority of diversity within this population. If identified, these accessions could be utilized for breeding and development of Miscanthus cultivars. Moreover, we aimed to verify the classification of accessions and define the method for genotype identification. In each accession particular attention was paid to the genetic diversity revealed by ISSR and RAPD molecular markers and ploidy level estimation by flow cytometry. The objectives of this paper focused on three of the Miscanthus species studied in Europe for biomass production: $M . \times$ giganteus, M. sacchariflorus, M. sinensis.

\section{Materials and Methods}

\section{Plant Material}

In total, 18 accessions representing the Miscanthus (Anderss.) species available in the field collection at the PBAI - NRI (Poland) were sampled (Fig. 1a-r). The material included: 12 ornamental varieties of $M$. sinensis, 3 clones ("Canada," "Germany," "Great Britain") of M. × giganteus, 2 ecotypes of $M$. sacchariflorus, and 1 genotype of $M$. floridulus (relabeled $M . \times$ giganteus "Floridulus"), which are listed in Table 1 . The studies were carried out during three vegetative seasons from 2010 to 2012.

\section{DNA Extraction}

DNA material was extracted from $1.0 \mathrm{~g}$ of fresh leaf material from five plants of each accession, using modified procedure according to Murray and Thompson [37]. The quantity and quality of total genomic DNA were determined by agarose gel electrophoresis and spectrophotometer UV-2100 (Shimadzu, Japan) absorbance at 230, 260, and $280 \mathrm{~nm}$. Only DNA samples with the OD 260/OD $280>1.8$ and OD 260/OD $230 \geq 2.0$ were diluted in sterile redistilled water and stored at $-20{ }^{\circ} \mathrm{C}$ until use.

\section{ISSR PCR}

ISSR-PCR reactions were performed in a $25 \mu \mathrm{L}$ volume of reaction mixture (Thermo Scientific, Fermentas, Germany) containing $25 \mathrm{ng}$ of template DNA, $200 \mu \mathrm{M}$ of each dNTP, $2.5 \mathrm{mM} \mathrm{MgCl}_{2}$, $0.7 \mathrm{U}$ Taq polymerase, $1 \times$ Taq Buffer and $1 \mu \mathrm{M}$ of each ISSR primer (Genomed, Poland) (Table 2). DNA was amplified in Mastercycler (Eppendorf, Germany) thermocycler and reaction conditions were as followed: $3 \mathrm{~min}$ at $94{ }^{\circ} \mathrm{C}$, followed by 40 cycles of $1 \mathrm{~min}$ at $94{ }^{\circ} \mathrm{C}$, $1 \mathrm{~min}$ at $41-64{ }^{\circ} \mathrm{C}$ (depending on the primer sequence), $1 \mathrm{~min}$ at $72{ }^{\circ} \mathrm{C}$, and a final extension cycle of $5 \mathrm{~min}$ at $72{ }^{\circ} \mathrm{C}$. Thirty-eight primers were tested, out of which 15 generated stable band pattern and were selected for further studies. Amplification products were separated using $1.7 \%$ agarose (Prona, Spain) gel in TBE buffer, stained with 

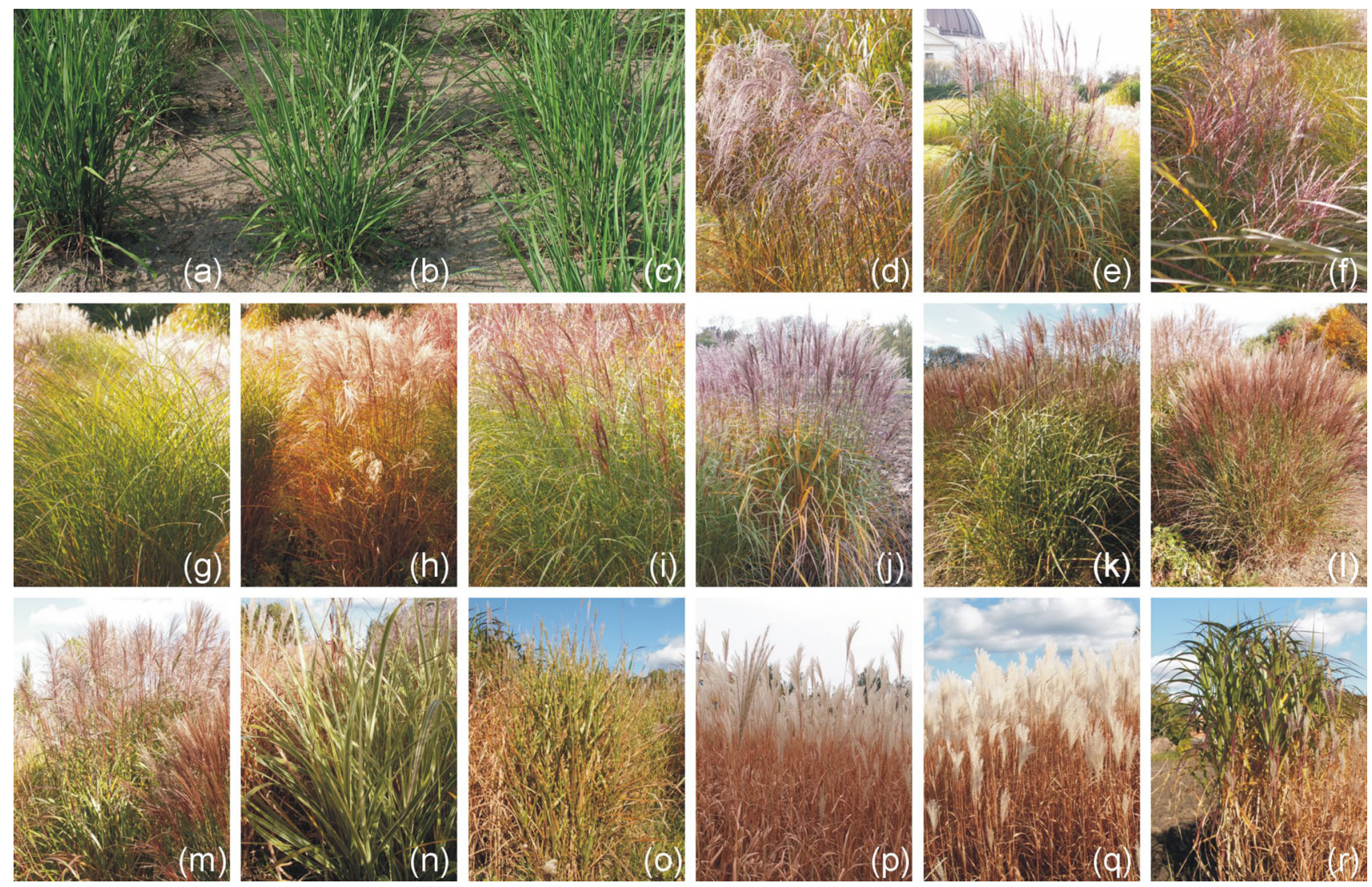

Fig. 1 The 18 characterized accessions representing Miscanthus species available in the field collection at the PBAI - NRI used in the study. a M. × giganteus "Canada," b $M . \times$ giganteus "Germany," c $M . \times$ giganteus "Great Britain," d $M$. sinensis "Flamingo," e $M$. sinensis "Goliath," f $M$. sinensis "Gracillimus," g M. sinensis "Graziella," g M. sinensis "Kleine Fontäne," h M. sinensis "Kleine

Silberspinne," i $M$. sinensis "Malepartus," j M. sinensis "Pünktchen," k M. sinensis "Rotsilber," l M. sinensis "Sirene," $\mathbf{m}$ M. sinensis "Variegatus," o M. sinensis "Zebrinus," p M. sacchariflorus ecotype I, q M. sacchariflorus ecotype II, $\mathbf{r}$ M. floridulus (relabeled as M. × giganteus "Floridulus")

ethidium bromide and visualized via GelDoc 2000 UV transilluminator (BioRad, Poland). The reactions were replicated three times with independent DNA extractions to confirm reproducibility of the results.

\section{RAPD PCR}

RAPD-PCR reactions consisted of the following components in $25 \mu \mathrm{L}$ volume of reaction mixture (Thermo Scientific, Fermentas, Germany): $25 \mathrm{ng}$ template DNA, $200 \mu \mathrm{M}$ of each dNTP, $2.5 \mathrm{mM} \mathrm{MgCl} 2,0.7 \mathrm{U} \mathrm{Taq}$ polymerase, $1 \times$ Taq Buffer, and $1 \mu \mathrm{M}$ of each RAPD primer (Genomed, Poland) (Table 2). The DNA amplification protocol was: $3 \mathrm{~min}$ at $94{ }^{\circ} \mathrm{C}$, followed by 40 cycles of $1 \mathrm{~min}$ at $94{ }^{\circ} \mathrm{C}, 1 \mathrm{~min}$ at $29-46{ }^{\circ} \mathrm{C}$ (depending on the primer sequence), $1 \mathrm{~min}$ at $72^{\circ} \mathrm{C}$, and a final extension cycle of $5 \mathrm{~min}$ at $72{ }^{\circ} \mathrm{C}$, conducted in Mastercycler (Eppendorf, Germany) thermocycler. Twenty-six primers were tested, out of which 11 generated stable band patterns and were selected for further studies. Amplification products

were electrophoresed in $1.7 \%$ agarose gel (Prona, Spain) and TBE buffer, stained with ethidium bromide and visualized via GelDoc 2000 UV transilluminator (BioRad, Poland). To confirm reproducibility of the results, all of the reactions were repeated three times, with independent DNA extractions.

\section{Ploidy Level by Flow Cytometry}

The young leaf tissue $\left(1 \mathrm{~cm}^{2}\right)$ of plants growing in the field was cut off and used for flow cytometry. Samples were prepared according to Galbraith [38] with some modifications. Plant tissue was chopped with razor blade in a Petri dish, containing $2 \mathrm{ml}$ of lysis buffer, with addition of $4^{\prime}, 6-$ diamidino-2-phenylindole (DAPI) and 2-mercaptoethanol. Suspensions were filtered and the analyses were performed using PAII (Partec, Germany) flow cytometer. For each leaf sample, 5,000-8,000 nuclei were analyzed in five replications, using a logarithmic scale. Histograms were 
Table 1 The 18 accessions representing the Miscanthus species available in the field collection at the PBAI - NRI used in the study: species, variety/ecotype/clone name, ploidy level

\begin{tabular}{|c|c|c|}
\hline Species & Variety/Ecotype/Clone name & $\begin{array}{l}\text { Ploidy } \\
\text { level }\end{array}$ \\
\hline M. sinensis & "Goliath" & $3 \times$ \\
\hline M. $\times$ giganteus & "Germany" & $3 \times$ \\
\hline M. floridulus & $\begin{array}{l}\text { Relabeled as } M . \times \text { giganteus } \\
\text { "Floridulus" }\end{array}$ & $3 \times$ \\
\hline M. $\times$ giganteus & "Great Britain" & $3 \times$ \\
\hline M. $\times$ giganteus & "Canada" & $3 \times$ \\
\hline M. sinensis & "Graziella" & $2 \times$ \\
\hline M. sinensis & "Kleine Fontäne" & $2 \times$ \\
\hline M. sinensis & "Flamingo" & $2 \times$ \\
\hline M. sinensis & "Malepartus" & $2 \times$ \\
\hline M. sinensis & "Sirene" & $2 \times$ \\
\hline M. sinensis & "Zebrinus" & $2 \times$ \\
\hline M. sinensis & "Pünktchen" & $2 \times$ \\
\hline M. sinensis & "Rotsilber" & $2 \times$ \\
\hline M. sacchariflorus & Ecotype I & $2 \times$ \\
\hline M. sacchariflorus & Ecotype II & $2 \times$ \\
\hline M. sinensis & "Kleine Silberspinne" & $2 \times$ \\
\hline M. sinensis & "Variegatus" & $2 \times$ \\
\hline M. sinensis & "Gracillimus" & $2 \times$ \\
\hline
\end{tabular}

analyzed with the use of a DPAC v.2.2 computer program (Partec Gmbh, Germany).

Data Analysis

The results of the ISSR-PCR and RAPD-PCR reactions across 18 accessions were processed in a binary system for band presence " 1 " or absence " 0 " for each primer. Only reliable, intensive bands were scored. The number of monomorphic and polymorphic amplification products generated by each primer of each marker system was determined. The binary data were used to estimate levels of polymorphism by dividing the polymorphic bands by the total number of bands scored. In agreement with Ghislain et al. [39] the polymorphic index content (PIC) was calculated by the formula: PIC $=1-p^{2}-q^{2}$, where $p$ is the band frequency and $q$ is no-band frequency. So as to show the information content of the ISSR and RAPD primer per assay, the PIC values across alleles for each locus were summed up and named ISSR and RAPD primer index, respectively. Estimates of the genetic similarity were calculated for all accessions according to Nei and $\mathrm{Li}$ [40] as follows: $F=2 n_{X Y} /\left(n_{X}+n_{Y}\right)$, where $n_{X}$ and $n_{Y}$ are the numbers of fragments in populations $X$ and $Y$, respectively, whereas $n_{X Y}$ is the number of fragments shared by the two populations. Following the terminology of Gower [41] cited by Reif et al. [42], dissimilarity coefficient $(d)$ was calculated as: $d=1-s$, where $s$ is the similarity coefficient. According to Gower [43], a dendrogram was constructed using the unweighted pair group method with arithmetic average (UPGMA) [44] and the principal coordinate analysis (PCoA) was performed. The Statistica 7.0 (StatSoft, Poland) software package was used for data management and statistical calculations.

\section{Results}

\section{ISSR and RAPD Marker Polymorphism}

Miscanthus species were screened using 15 ISSR primers, which produced reproducible polymorphic banding patterns. A total of 443 bands were scored, of which 435 (98\%) were polymorphic. The number of bands generated per primer varied from 12 to 40 . The approximate size of the amplified products ranged from 23 to $3,365 \mathrm{bp}$. To characterize the capacity of each marker to reveal polymorphic loci among the germplasm, we mainly used the ISSR primer index (Table 2), which revealed that primers: ISSR1, ISSR2, ISSR3 are the most efficient for subsequent fingerprint research in the Miscanthus species.

Out of 11 RAPD primers, a total of 155 bands were scored and 145 (94\%) were polymorphic. Amplified DNA fragments varied in size from 138 to $1,613 \mathrm{bp}$, with 6-29 bands per primer. The RAPD primer index (Table 2) showed that primers: RAPD1, RAPD2, RAPD3, RAPD4 are the most efficient for subsequent fingerprint research in the Miscanthus species.

\section{Genotype and Species-Specific Diagnostic Markers}

Both ISSR and RAPD marker systems could successfully distinguish the 18 Miscanthus accessions. Only one primer for ISSR (ISSR1) (Fig. 2a) and three primers for RAPD (RAPD1 (Fig. 2b), RAPD2, RAPD4) were needed to identify all genotypes. The first marker technique from the above mentioned revealed 16 unique bands which were genotype-specific in 8 accessions, whereas the second one revealed 64 unique bands in all accessions. Interestingly, we received accession-specific products of amplification for $M . \times$ giganteus genotypes as follows: 2 for "Canada," 1 for "Germany," and 2 for "Great Britain." For M. floridulus, we found five accession-specific bands.

In the current study, we searched for amplification products that would be present in every genotype of given species, but absent in others. For $M . \times$ giganteus clones seven (4 ISSR and 3 RAPD), for $M$. sinensis varieties one (ISSR) and for M. sacchariflorus ecotypes eight (5 ISSR and 3 RAPD) species-specific bands were recognized. 
Table 2 List of 15 ISSR and 11 RAPD polymorphic primes, total number of amplified bands, number of polymorphic bands, polymorphism percentage, ISSR primer index, and RAPD primer index, primer sequence used in molecular characterization of 18 Miscanthus accessions available in the field collection at the PBAI - NRI

\begin{tabular}{|c|c|c|c|c|c|}
\hline Primer & $\begin{array}{l}\text { Total no. } \\
\text { of bands }\end{array}$ & $\begin{array}{l}\text { No. of } \\
\text { polymorphic } \\
\text { bands }\end{array}$ & $\begin{array}{l}\text { Percent } \\
\text { polymorphism } \\
(\%)\end{array}$ & $\begin{array}{l}\text { ISSR/RAPD } \\
\text { primer index }\end{array}$ & Primer sequence \\
\hline \multicolumn{6}{|l|}{ ISSR } \\
\hline ISSR1 & 40 & 40 & 100 & 14.22 & $(\mathrm{CTG})_{7} \mathrm{G}$ \\
\hline ISSR2 & 35 & 35 & 100 & 12.67 & $(\mathrm{GAG})_{6} \mathrm{C}$ \\
\hline ISSR3 & 34 & 34 & 100 & 12.49 & $(\mathrm{GAC})_{6} \mathrm{~T}$ \\
\hline ISSR4 & 37 & 37 & 100 & 10.96 & $(\mathrm{GACA})_{5}$ \\
\hline ISSR5 & 36 & 35 & 97 & 10.40 & $(\mathrm{GTC})_{6} \mathrm{~A}$ \\
\hline ISSR6 & 37 & 36 & 97 & 10.33 & $(\mathrm{GTG})_{6} \mathrm{C}$ \\
\hline ISSR7 & 31 & 30 & 97 & 10.02 & $(\mathrm{CTC})_{7}$ \\
\hline ISSR8 & 32 & 32 & 100 & 9.88 & $(\mathrm{GTG})_{6} \mathrm{~A}$ \\
\hline ISSR9 & 26 & 26 & 100 & 9.07 & $(\mathrm{AC})_{8} \mathrm{TG}$ \\
\hline ISSR10 & 31 & 30 & 97 & 8.92 & $(\mathrm{GAC})_{6}$ \\
\hline ISSR11 & 25 & 23 & 92 & 8.03 & $(\mathrm{GACA})_{4}$ \\
\hline ISSR12 & 26 & 26 & 100 & 7.36 & $(\mathrm{CTC})_{7} \mathrm{~A}$ \\
\hline ISSR13 & 26 & 25 & 96 & 6.95 & $(\mathrm{GACA})_{4} \mathrm{~A}$ \\
\hline ISSR14 & 14 & 14 & 100 & 4.14 & $(\mathrm{TC})_{8} \mathrm{AG}$ \\
\hline ISSR15 & 13 & 12 & 92 & 2.85 & TG(TACA) $)_{4}$ \\
\hline Mean & 30 & 29 & 98 & 9.22 & - \\
\hline Total & 443 & 435 & - & - & - \\
\hline \multicolumn{6}{|l|}{ RAPD } \\
\hline RAPD1 & 30 & 29 & 97 & 9.23 & CCA GCC GAA C \\
\hline RAPD2 & 26 & 26 & 100 & 8.46 & $\begin{array}{l}\text { CCA GCC GAA C } \\
\text { ATG GAT CCG C }\end{array}$ \\
\hline RAPD3 & 16 & 16 & 100 & 6.02 & GTT GCC AGC C \\
\hline RAPD4 & 16 & 15 & 94 & 4.77 & AGG GAA CGA G \\
\hline RAPD5 & 12 & 12 & 100 & 4.67 & AGC GCC ATT G \\
\hline RAPD6 & 12 & 10 & 83 & 3.80 & CCA AGC TGC C \\
\hline RAPD7 & 12 & 10 & 83 & 3.35 & ACC CGG TCA C \\
\hline RAPD8 & 10 & 8 & 80 & 2.87 & GGG CTC ATA G \\
\hline RAPD9 & 8 & 6 & 75 & 2.49 & ATG GAT CCG C \\
\hline RAPD10 & 7 & 7 & 100 & 2.28 & AGG TGA ACG G \\
\hline RAPD11 & 6 & 6 & 100 & 1.80 & CGA GTG CCT A \\
\hline Mean & 14 & 13 & 94 & 4.52 & - \\
\hline Total & 155 & 145 & - & - & - \\
\hline
\end{tabular}

Considerably higher genetic similarity (0.74) was found between $M . \times$ giganteus and M. floridulus accessions.

Cluster Analysis

Cluster analysis based on the matrix of Nei and Li [40] genetic dissimilarity coefficient using UPGMA (Fig. 3) grouped the 18 accessions in three clusters according to species affiliation, apart from M. floridulus, which was closely related to $M . \times$ giganteus. The results indicated that the $M . \times$ giganteus "Canada" was more similar to the $M . \times$ giganteus "Germany" than it was to $M . \times$ giganteus "Great Britain," but the level of variation was very low. The M. × giganteus "Great Britain" was equidistant from the 

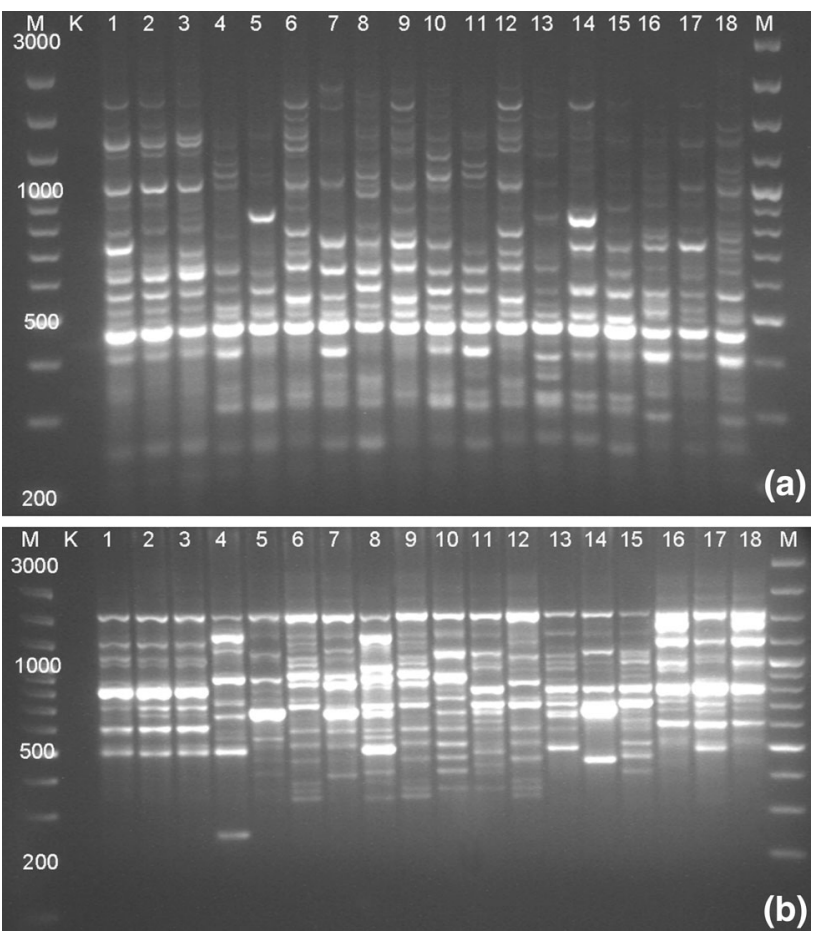

Fig. 2 Products of amplification obtained for 18 Miscanthus accessions available in the field collection at the PBAI - NRI with the use of selected primers: a ISSR1 and b RAPD1. Lane M, DNA ladder; K, negative DNA control; $1, M . \times$ giganteus "Canada"; $2, M . \times$ giganteus "Germany"; 3, M. $\times$ giganteus "Great Britain"; 4, M. sinensis "Flamingo"; 5, M. sinensis "Goliath"; 6, M. sinensis "Gracillimus"; 7, M. sinensis "Graziella"; 8, M. sinensis "Kleine Fontäne"; 9, M. sinensis "Kleine Silberspinne"; 10, M. sinensis "Malepartus"; 11, M. sinensis "Pünktchen"; 12, M. sinensis "Rotsilber"; 13, M. sinensis "Sirene"; 14, M. sinensis "Variegatus"; 15, M. sinensis "Zebrinus"; 16, M. sacchariflorus (ecotype I); 17, M. sacchariflorus (ecotype II)*; 18, M. floridulus (relabeled as $M . \times$ giganteus "Floridulus")*. *b line number 17 is represented by $M$. floridulus (relabeled as M. $\times$ giganteus "Floridulus") and line number 18 by $M$. sacchariflorus (ecotype II)

above mentioned clones. The use of combined ISSR and RAPD markers showed that $M . \times$ giganteus was more closely related to $M$. sacchariflorus than to $M$. sinensis. All the genotypes of $M$. sinensis were grouped together, with the separation on three subclusters. The first one consisted of: "Flamingo," "Kleine Fontäne," "Goliath," "Malepartus" and "Pünktchen"; the second consisted of: "Gracillimus," "Kleine Silberspinne," "Rotsilber" and "Graziella"; the third consisted of: "Sirene," "Variegatus" and "Zebrinus."

\section{Principal Coordinate Analysis}

Similar groupings were evident in the PCoA analysis (Fig. 4). The first and the second coordinates (designated as PCo1 and PCo2) displayed 33.5 and $17.6 \%$ of the total variation in the combined ISSR and RAPD data. In the first dimension $M$. sacchariflorus, $M . \times$ giganteus and $M$. floridulus almost did not differ from each other, whereas the difference was clearly seen, not only between the above mentioned accessions and the genotypes of M. sinensis, but also within the latter species. Calculating the second dimension enabled the discrimination between $M$. sacchariflorus, $M . \times$ giganteus and M. floridulus accessions. The M. floridulus was distinct in its distance to the $M . \times$ giganteus in the second dimension.

\section{Ploidy Level by Flow Cytometry}

The ploidy level of all accessions was estimated using flow cytometry, where a reference diploid $M$. sinensis was used as an external standard ( $2 \mathrm{C}$ and $4 \mathrm{C}$ peak adjusted to channels 100 and 200, respectively). Figure 5 shows two types of histograms: diploid-control (Fig. 5a), diploid $M$. sinensis "Flamingo" (Fig. 5b) and triploid M. sinensis "Goliath" (Fig. 5c). In our study almost all genotypes from each species did not differ in ploidy level (Table 1). Flow cytometric analyses performed in the same conditions showed that $2 \mathrm{C}$ and $4 \mathrm{C}$ peaks of $M$. sacchariflorus ecotypes and 11 varieties of $M$. sinensis (apart from "Goliath") were situated in the same channel as standard, thus were diploids. In contrast, for $M . \times$ giganteus clones, $M$. floridulus and M. sinensis "Goliath" $3 \mathrm{C}$ peak was found in channel 150 and $6 \mathrm{C}$ peak was found in channel 300 , which means that those species were triploids.

\section{Discussion}

In Miscanthus breeding, the collection and use of diverse germplasms is indispensable. According to Tessier et al. [45] recognition of young plants during multiplication or international exchanges cause many problems in identification of different vegetatively propagated breeding lines. Based only on morphological observations, identification of each species in different vegetative stages, field conditions (environmental variability) or during in vitro propagation is not always sufficient and sometimes even impossible. Hence, an inexpensive, fast and low labor molecular and cytological technique to characterize genotypes and evaluate the genetic diversity is needed.

For that purpose, both ISSR and RAPD marker systems were used in identification of 18 Miscanthus accessions. It is worth emphasizing that the comparison of efficiency and utility between ISSR and RAPD markers has not been done in Miscanthus, till date. The ISSR method showed slightly higher polymorphism percentage $(98 \%)$ as well as wider product size range compared to RAPD marker system $(94 \%)$. Considering the fact that the greatest challenge in variety identification is to reduce the number of amplifications and thus the number of primers, which would lower 


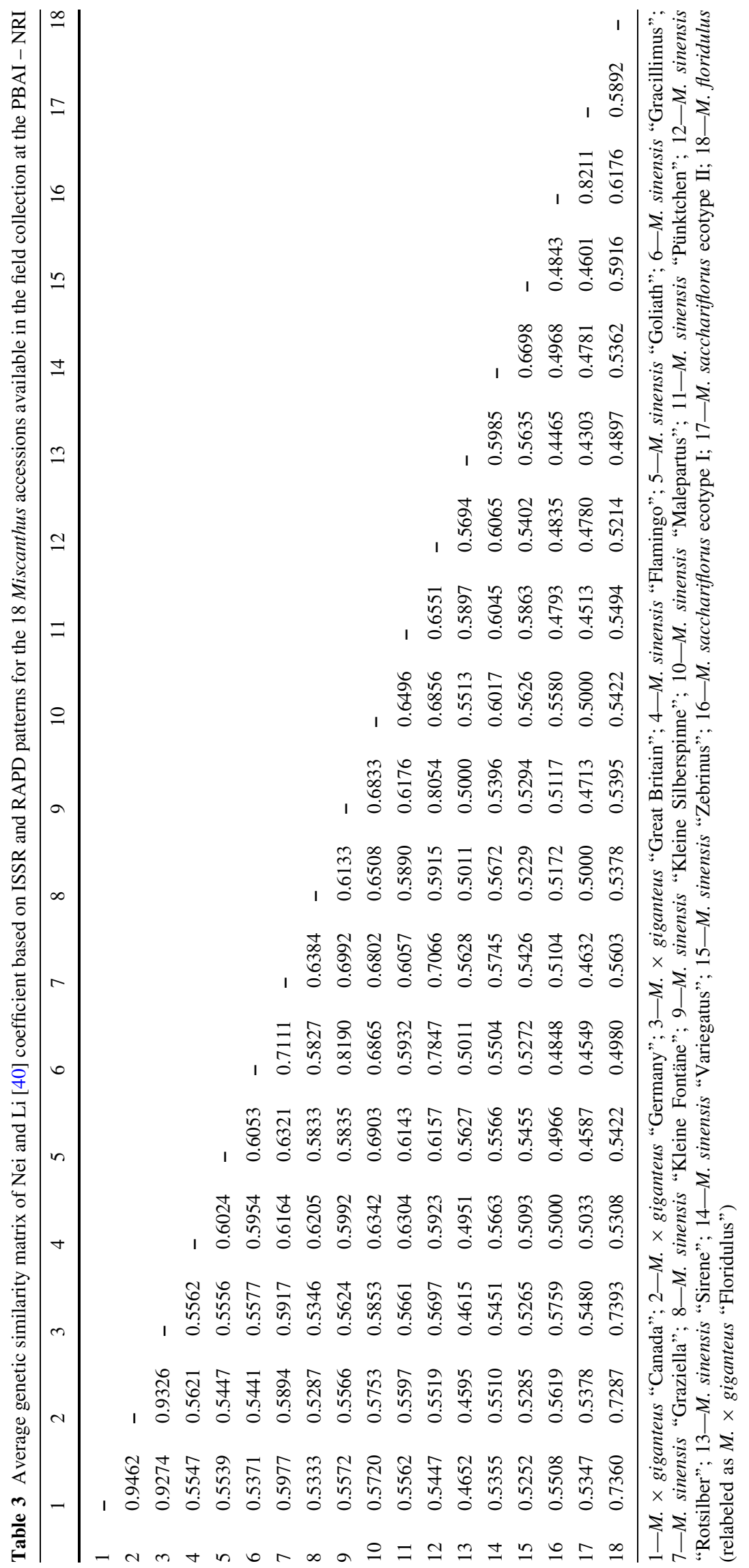


Fig. 3 Dendrogram of cluster analysis including 18

Miscanthus accessions available in the field collection at the PBAI - NRI constructed from combined ISSR and RAPD data using UPGMA method based on Nei and Li [40] measure of similarity

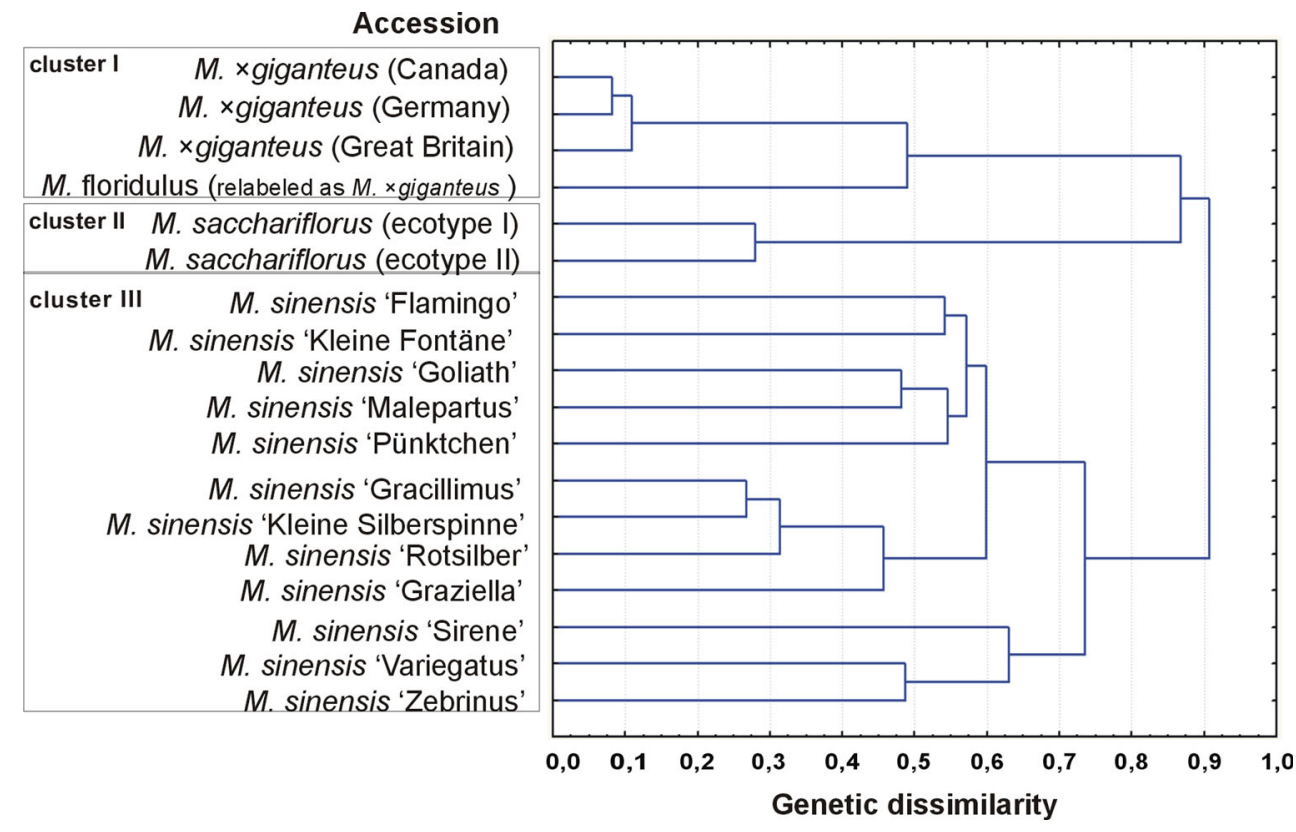

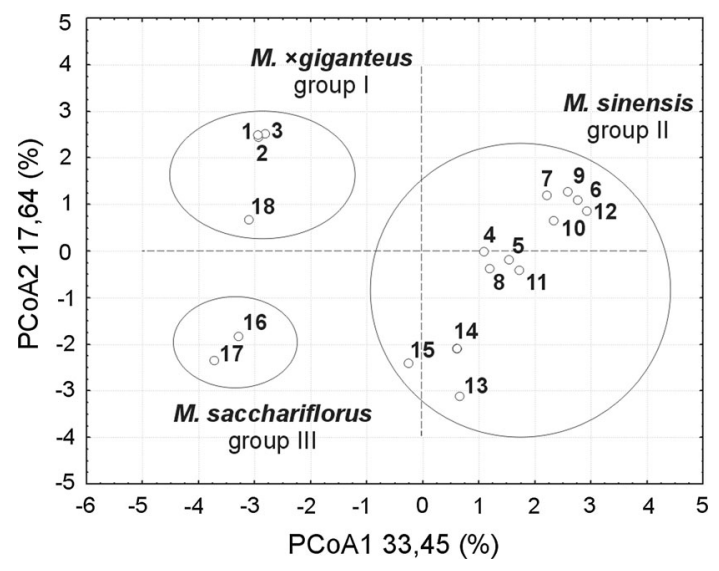

Fig. 4 PCoA plot showing the distribution of 18 Miscanthus accessions available in the field collection at the PBAI - NRI (Poland) in system of the first two principal coordinates constructed using Nei and Li [40] measure of similarity based on combined ISSR and RAPD data. Numbers given on the chart refer to as follows: 1, $M . \times$ giganteus "Canada"; 2, M. × giganteus "Germany"; 3, M. $\times$ giganteus "Great Britain"; 4, M. sinensis "Flamingo"; 5, M. sinensis "Goliath"; 6, M. sinensis "Gracillimus"; 7, M. sinensis "Graziella"; 8, M. sinensis "Kleine Fontäne"; 9, M. sinensis "Kleine Silberspinne"; 10, M. sinensis "Malepartus"; 11, M. sinensis "Pünktchen"; 12, M. sinensis "Rotsilber"; 13, M. sinensis "Sirene"; 14, M. sinensis "Variegatus"; 15, M. sinensis "Zebrinus"; 16, M. sacchariflorus (ecotype I); 17, M. sacchariflorus (ecotype II); 18, $M$. floridulus (relabeled as $M . \times$ giganteus "Floridulus"). The accessions can be distinguished using the first two principal coordinates (PCoA1 and PCoA2) and this cumulatively account for $51.09 \%$ (33.45\% and $17.64 \%$, respectively) of the data variance

the cost of analysis [45], we recognized the first method as more efficient than the second one. In the current work, ISSR technique revealed higher mean number of polymorphic bands (29) compared to RAPD (13). If it comes to the mean value of marker index, which reveals the information content of primer per assay, likewise it was higher for ISSR (9.22) than RAPD (4.52) markers.

Moreover, the use of only one PCR with the most polymorphic ISSR primer (ISSR1) was enough to distinguish all 18 accessions, whereas RAPD technique required at least three reactions (RAPD1, RAPD2, RAPD4), which would potentially triple the analysis cost. Archak et al. [46] indicated that the cost of ISSR and RAPD analysis per assay of 19 samples was the same for both techniques (USD 80.00), but the cost per polymorphic marker generated was lower in ISSR (USD 7.60) in comparison with RAPD (USD 8.0). To our knowledge, the comparison of these two marker systems has not been done in Miscanthus till date, but our observations stay in agreement with results obtained by Esselman et al. [47] who showed higher ISSR than RAPD diversity within four populations of clonally propagated grass Calamagrostis porteri ssp. insperta. The ISSR method has also been reported to be more useful then RAPD for cultivar identification in numerous plant species, including peanut [48], rice [49], chickpea [50], barley [51], sugarcane [52], and pepper [53]. The distinction between the above mentioned marker systems may concern a different nature of the primer sequence and the amplification of distinct genomic regions. For instance, there is a probability that RAPD bands are associated with functionally important loci, dispersed throughout the genome, whereas ISSR bands are not supposed to be under functional constrains, thus they evolve rapidly and are responsible for higher variability [47]. Moreover, the ISSR markers amplify regions rich in microsatellites, which cause the higher level of polymorphism because of mutations 

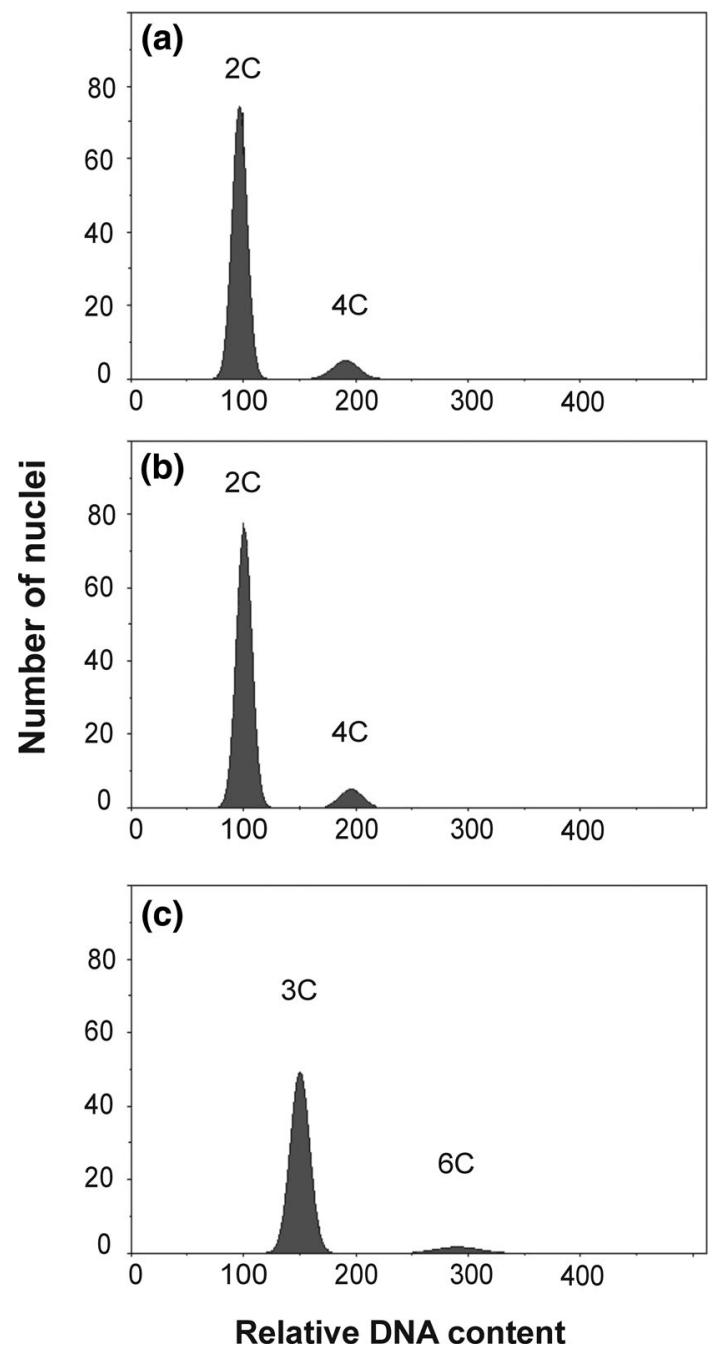

Fig. 5 Selected histograms of relative DNA content obtained after analysis of isolated nuclei from Miscanthus species. a Diploid-a reference $M$. sinensis as a ploidy level control, b diploid $M$. sinensis "Flamingo" and $\mathbf{c}$ triploid $M$. sinensis "Goliath"

induced by unequal crossing-over and the DNA polymerase slippage during replication [52]. Nevertheless, sometimes only single amplification product of RAPD technique can prove useful in species identification. Kim et al. [34], based on one unique RAPD fragment of M. sacchariflorus developed SCAR markers for simultaneous distinction of the M. sacchariflorus, M. sinensis, and M. $\times$ giganteus species.

In our study, we aimed at finding species-specific markers, which would help in classification of currently retained plant material in field collections and would be useful in verifying the labels of new accessions that can broaden genetic base in the future. For that reason, the use of ISSR technique turned out to be the only possibility in $M$. sinensis, whereas in $M . \times$ giganteus and $M$. sacchariflorus it was more efficient than RAPD marker system.
Next step will be to characterize the usefulness of obtained markers in evaluating species identity on larger number of accessions. Moreover, according to Awasthi et al. [54] and Kim et al. [34], further analysis is needed to develop robust species-specific markers so that unique products, after sequencing and designing suitable primers, could be converted to sequence characterized amplification regions (SCARs). Interestingly, despite the presence of five unique accession-specific bands generated by ISSR technique, amplification profiles for $M$. floridulus obtained using this marker system showed very similar banding patterns to M. × giganteus. Also morphological observations (i.e., inflorescence), nuclear DNA content (data not shown) and ploidy level estimation indicated that this triploid plant, probably incorrectly labeled as M. floridulus, should be named as $M . \times$ giganteus "Floridulus."

At first it seemed that incidental mislabeling appeared during molecular characterizations of Miscanthus germplasm collections, which happened as previously mentioned by Greef et al. [13] and Hodkinson et al. [17], but later it turned out that mislabeling of M. floridulus is quite frequent. As described in the study by Hodkinson et al. [7, 17], the Neighbor Joining tree of AFLP data revealed that M. floridulus (Labill.) Warb. Ex K. Schum. \& Lauterb. was grouped with $M$. sinensis accessions and its species status was questionable. Similar results were obtained by Chae [55] for two diploid accessions of M. floridulus, which based on the combined morphology, genome size and molecular data, each grouped with $M$. sinensis. The errors in the taxonomic identification between M. floridulus and $M$. sinensis, which sometimes cannot be clarified by analytical methods, can be explained by the fact that distribution of these species in the native environment of Pacific region are convergent and thus some intermediates may have appeared [17, 22]. Chouvarine et al. [56] during highthroughput exome sequencing analysis of seven different Miscanthus plants aimed at the distinction between closely related genotypes and showed that one plant, named $M$. floridulus, proved to be $M . \times$ giganteus. According to Baldwin [25] misidentified M. floridulus indicated the similarity to $M . \times$ giganteus, but also proved to be potential material for development of a new $M . \times$ giganteus cultivar with good morphologic and breeding features of the plant grown under natural conditions (Oktibbeha Country, Mississippi) in comparison with $M . \times$ giganteus "Illinois." Moreover, Zub et al. [27] performed the identification of key traits for biomass production of 21 clones of four Miscanthus species at two harvest dates in Northern France. Results indicated that triploid M. floridulus named "M. floridulus giganteus" displayed significantly higher canopy and panicle height and shoot diameter than $M . \times$ giganteus clones and the highest value of mean biomass yield (20 t/ha) during second and third crop year 
in the tested plant group. Authors assumed that it could be hidden cv. M. floridulus belonging to the M. $\times$ giganteus species [57].

Because of the above mentioned facts, the overarching objective of our study was to characterize the genetic relationship among all the tested accessions, with the particular attention paid to mislabeled $M$. floridulus genotype and three $M . \times$ giganteus clones. The value of mean dissimilarity coefficient between mislabeled $M$. floridulus and $M$. $\times$ giganteus clones was higher (0.26) than mean dissimilarity coefficient between $M . \times$ giganteus clones (0.06). The UPGMA analysis, based on Nei and Li [40] measure of similarity showed that all M. $\times$ giganteus genotypes were grouped in one cluster, but were closely related to mislabeled $M$. floridulus, which stayed separately. That was also confirmed in the PCoA analysis. In the first dimension genotypes mentioned above almost did not differ from each other, but the second dimension indicated that mislabeled $M$. floridulus had a distinct distance from $M . \times$ giganteus accessions.

Interestingly, as Baldwin [25] described, such mislabeled genotype of $M$. floridulus, later classified as $M . \times$ giganteus, was a valuable source for the selection of a new cultivar "MSU MFL1" that differed from the "Illinois" clone and other genotypes on the market, giving higher biomass yields.

Moreover, flow cytometry analysis of ploidy level and RAPD molecular markers confirmed the clonal nature of $M$. $\times$ giganteus genotypes, whereas with the use of ISSR technique we received accession-specific products of amplification for $M . \times$ giganteus genotypes. However, further characterization of upon mentioned bands is needed. Cluster analysis indicated that the M. $\times$ giganteus "Canada" was more similar to the $M . \times$ giganteus "Germany" than it was to $M$. × giganteus "Great Britain," but the level of variation was very low.

In the study made by Głowacka et al. [18] only five accessions of $32 \mathrm{M} . \times$ giganteus legacy cultivars and three of the eight $M . \times$ giganteus polyploids differed for at least one nuclear SSR allele. Authors assumed that genetic diversity within the analyzed group of genotypes from America and Europe nearly did not exist and new crosses would provide genetic variation for this species. According to Greef et al. [13], who evaluated middle European $\mathrm{Mi}$ scanthus species pool with the use of AFLP markers, genetic diversity among 32 accessions of $M . \times$ giganteus was very low and only three accessions could be distinguished from the other. Hodkinson et al. [17] with the use of ISSR markers did not detect genetic variation between M. $\times$ giganteus accessions and that confirmed the clonal nature of analyzed plants. However, the use of AFLP markers enabled detection of a low rate of genetic variation in $M . \times$ giganteus accessions. It allowed to hypothesize that there may be only two or three cultivated clones of M. $\times$ giganteus.

Chouvarine et al. [56] indicated, the availability of multiple genotypes of $M . \times$ giganteus with the use of Illumina high-throughput exome sequencing coupled with SNP mapping and proved that three cultivars studied ("Freedom," "Illinois," and "Canada") are genetically different, which can be exploited in future cultivar development. Unfortunately, the above mentioned studies did not provide technical replications and though it was difficult to verify if the differences are caused by one or more somatic mutations among $M . \times$ giganteus accessions or by sequencing error as it was mentioned by Głowacka et al. [18]. Nevertheless, for introduced populations, which are exposed at novel selection conditions, the genetic differentiation may exist in any ecological trait, which is beneficial [58]. Moreover, in natural environment Miscanthus is growing from the subarctic to the subtropics [22]. Nishiwaki et al. [59] founded three different genotypes of $M . \times$ giganteus species, which existed in overlapping populations of $M$. sinensis and $M$. sacchariflorus across Japan and the nucleotide polymorphisms between the sequences of ribosomal DNA internal transcribed spacer (ITS) region were detected. Father investigation in sympatric areas may reveal more natural hybrids between tetraploid $M$. sacchariflorus and diploid M. sinensis [60]. On the other hand, serial propagation is a technique that exploits slight somatic mutations occurring in the meristems of vegetatively propagated plants in order to enable selection of individuals with improved cultivation features [24]. This could probably indicate that $M . \times$ giganteus genotypes "Canada," "Germany" and "Great Britain" characterized in our study belong to one clone origin with the slight differences in genome sequence. However, mislabeled $M$. floridulus, which proved to be $M . \times$ giganteus, may represent the second clone origin, perhaps widespread in Europe and America, which represents another different hybridization event. The above mentioned hypothesis will be verified by further studies with the use of more advanced molecular techniques such as high-throughput exome sequencing or by a wider range of $M$. sinensis and M. sacchariflorus accessions as potential maternal components of $M . \times$ giganteus.

On the contrary, we detected that, based on ISSR and RAPD markers, the genetic diversity among M. sinensis genotypes was relatively high. That stays in agreement with a number of other studies [13, 17, 29, 36, 61]. Taking into consideration the UPGMA analysis we assigned three subclusters in $M$. sinensis cluster. Those results agreed with PCoA, apart from M. sinensis "Malepartus," which proved higher correlation with accessions from the fourth group of UPGMA analysis. The highest genetic similarity was observed between "Gracillimus" and "Kleine 
Silberspinne" (0.82). Analyzing the neighbor joining tree of AFLP data of M. sinensis accessions revealed by Hodkinson et al. [17], similar grouping between "Goliath" and "Malepartus" can be found. The differences between accessions were quite clearly seen also in genotypes' phenotypic appearance. Apart from the fact that many ornamental $M$. sinensis cultivars characterize with early flowering and short height, which is undesirable for biomass production [22], a huge phenotypic diversity in a wide range of traits was identified in the UK national collection of Miscanthus species among M. sinensis genotypes. It is worth emphasizing that those features were connected with yield and quality of plants. The wide geographical distribution may have contributed to that [6] and it can be explained by the different types of reproduction (cross-pollination), ecological habits [36] or as a consequence of breeding selection directed at ornamental values. Moreover, there is a higher probability that genetically differentiated populations better survive distinct environmental conditions [61]. As Farrell et al. [62] indicated $M$. sinensis cultivars are more cold tolerant that $M . \times$ giganteus and, next to the $M$. sacchariflorus, can be used as maternal components for the development of new hybrids [63], for studying of the inheritance of important traits [22] and in comparative genomics for understanding the relationships with other species such as sorghum [21]. In our observations two ecotypes of $M$. sacchariflorus were tested, but they showed rather low genetic diversity and the same ploidy level. As Sacks et al. [22] mentioned M. sacchariflorus "Robustus" is planted in living collections or many botanic gardens in Europe and the USA. In order to confirm such origin of $M$. sacchariflorus genotypes analyzed here more studies are needed. It is important to appreciate that the international code of botanic nomenclature defines the hybrid names by its parental components so their ploidy levels should be defined and available [22]. In the above study the ploidy level in Miscanthus species ranges from diploid to hexaploid. Basal ploidy in M. sinensis is diploid, but natural and artificial polyploids are also common e. g. M. sinensis "Goliath" (triploid) [6, 13]. Although M. sacchariflorus is normally diploid [22], in this species there is a whole range of ploidy up to hexaploid [6]. As previously mentioned, $M . \times$ giganteus is an interspecific hybrid for which parental components are M. sinensis and M. sacchariflorus [12] and its ploidy level is typically triploid. However, tetra- and pentaploids, which are produced by artificial hybridizations, may potentially improve biomass cultivars [22]. Our study showed that the need to characterize and broaden the genetic base of M. $\times$ giganteus gene pool still exists not only in Poland, but also in Europe. Moreover, the use of multiple techniques to characterize accessions in field collections is needed. In accordance with previously mentioned studies, it seems that more investigations are required for $M$. floridulus taxonomic recognition as a potential source for genetic improvement of Miscanthus species in European conditions [57].

Acknowledgments The authors thank Dr. D.R. Mańkowski of the Department of Seed Science and Technology, Laboratory of Seed Production and Plant Breeding Economics, a resource of the Plant Breeding and Acclimatization Institute-National Research Institute, for his assistance. The authors also thank K. Strycharczuk of the Cytogenetic Laboratory at the KHBC Sp. z o. o. [Ltd.], for her assistance.

Open Access This article is distributed under the terms of the Creative Commons Attribution License which permits any use, distribution, and reproduction in any medium, provided the original author(s) and the source are credited.

\section{References}

1. Heaton, E. A., Clifton-Brown, J., Voigt, T. B., Jones, M. B., \& Long, S. P. (2004). Miscanthus for renewable energy generation: European Union experience and projections for Illinois. Mitigation and Adaptation Strategies for Global Change, 9, 433-451.

2. Smeets, E. M. W., Lewandowski, I. M., \& Faaij, A. P. C. (2009). The economical and environmental performance of miscanthus and switchgrass production and supply chains in a European setting. Renewable \& Sustainable Energy Reviews, 13, 1230-1245.

3. Stampfl, P. F., Clifton-Brown, J. C., \& Jones, M. B. (2007). European-wide GIS-based modelling system for quantifying the feedstock from Miscanthus and the potential contribution to renewable energy targets. Global Change Biology Bioenergy, 13, 2283-2295.

4. Hastings, A., Clifton-Brown, J., Wattenbach, M., Mitchell, C. P., Stampfl, P., \& Smith, P. (2009). Future energy potential of Miscanthus in Europe. Global Change Biology Bioenergy, 1, 180-196.

5. Heaton, E. A., Voigt, T., \& Long, S. P. (2004). A quantitative review comparing the yields of two candidate $\mathrm{C}_{4}$ perennial biomass crops in relation to nitrogen, temperature and water. Biomass and Bioenergy, 27, 21-30.

6. Clifton-Brown, J., Chiang, Y.-C., \& Hodkinson, T. R. (2008). Miscanthus: Genetic resources and breeding potential to enhance bioenergy production. In W. Vermerris (Ed.), Genetic improvement of bioenergy crops (pp. 273-294). New York: Springer.

7. Hodkinson, T. R., Chase, M. W., Lledo, M. D., Salamin, N., \& Renvoize, S. A. (2002). Phylogenetics of Miscanthus, Saccharum and related genera (Saccharinae, Andropogoneae, Poaceae) based on DNA sequences from ITS nuclear ribosomal DNA and plastid trnL intron and trnL-F intergenic spacers. Plant Research, 115, 381-392.

8. Clifton-Brown, J. C., Lewandowski, I., Andersson, B., Basch, G., Christian, D. G., Bonderup-Kjeldsen, J., et al. (2001). Performance of 15 Miscanthus genotypes at five sites in Europe. Agronomy Journal, 93, 1013-1019.

9. Zub, H. W., \& Brancourt-Hulmel, M. (2010). Agronomic and physiological performances of different species of Miscanthus, a major energy crop: A review. Agronomy for Sustainable Development, 30, 201-214.

10. Linde-Laursen, I. (1993). Cytogenetic analysis of Miscanthus 'Giganteus', an interspecific hybrid. Hereditas, 119, 297-300. 
11. Hernández, P., Dorado, G., Laurie, D. A., Martín, A., \& Snape, J. W. (2001). Microsatellites and RFLP probes from maize are efficient sources of molecular markers for the biomass energy crop Miscanthus. Theoretical and Applied Genetics (TAG), 102, 616-622.

12. Hodkinson, T. R., Chase, M. W., Takahashi, C., Leitch, I. J., Bennett, M. D., \& Renovoize, S. A. (2002). The use of DNA sequencing (ITS and trnL-F), AFLP, and fluorescent in situ hybridization to study allopolyploid Miscanthus (Poaceae). American Journal of Botany, 89, 279-286.

13. Greef, J. M., Deuter, M., Jung, C., \& Schondelmaier, J. (1997). Genetic diversity of European Miscanthus species revealed by AFLP fingerprinting. Genetic Resources and Crop Evolution, 44, 185-195.

14. Atkinson, C. J. (2009). Establishing perennial grass energy crops in the UK: A review of current propagation options for Miscanthus. Biomass and Bioenergy, 33, 752-759.

15. Gubišová, M., Gubiš, J., Žofajová, A., Mihálik, D., \& Kraic, J. (2013). Enhanced in vitro propagation of Miscanthus $\times$ giganteus. Industrial Crops and Products, 41, 279-282.

16. Rayburn, A. L., Crawford, J., Rayburn, C. M., \& Juvik, J. A. (2009). Genome size of three Miscanthus species. Plant Molecular Biology Reporter, 27, 184-188.

17. Hodkinson, T. R., Chase, M. W., \& Renvoize, S. A. (2002). Characterization of a genetic resource collection for Miscanthus (Saccharinae, Andropogoneae, Poaceae) using AFLP and ISSR PCR. Annals of Botany, 89, 627-636.

18. Głowacka, K., Clark, L. V., Adhikari, S., et al. (2014). Genetic variation in Miscanthus $\times$ giganteus and the importance of estimating genetic distance thresholds for differentiating clones. Global Change Biology Bioenergy. doi:10.1111/gcbb.12166.

19. Glowacka, K., Adhikari, S., Stewart, R. J., Nishiwaki, A., Yamada, T., Jørgensen, U., Hodkinson, T. R., Gifford, J., Juvik, J. A., Sacks, E. J. (2013) Genetic diversity in Miscanthus $\times$ giganteus: an abstract nr P0719. In: Plant and Animal Genome XXI, online materials. Retrieved 25 October, 2013, https://pag.confex.com/ pag/xxi/webprogram/Paper7634.html.

20. De Cesare, M., Hodkinson, T. R., \& Barth, S. (2010). Chloroplast DNA markers (cpSSRs, SNPs) for Miscanthus, Saccharum and related grasses (Panicoideae, Poaceae). Molecular Breeding, 26, 539-544.

21. Ma, X. F., Jensen, E., Alexandrov, N., Troukhan, M., Zhang, L., Thomas-Jones, S., et al. (2012). High resolution genetic mapping by genome sequencing reveals genome duplication and tetraploid genetic structure of the diploid Miscanthus sinensis. PLoS One, 7, $1-11$.

22. Sacks, E. J., Juvik, J. A., Lin, Q., Stewart, J. R., \& Yamada, T. (2013). The gene pool of Miscanthus species and its improvement. In A. H. Paterson (Ed.), Genomics of the Saccharinae (Vol. 11, pp. 73-100)., Plant Genetics and Genomics: Crops and Models New York: Springer.

23. Clifton-Brown, J. C., \& Lewandowski, I. (2000). Overwintering problems of newly established Miscanthus plantations can be overcome by identifying genotypes with improved rhizome cold tolerance. New Phytologist, 148, 287-294.

24. Deuter, M., Abraham, J. (1998) Genetic resources of Miscanthus and their use in breeding. In Biomass for energy and industry, proceedings of the 10th European conference and technology exhibition, Wurzburg (pp. 775-777).

25. US Patent No. US 2013/0025014 P1. Miscanthus plant named 'MSU-MFL1'.

26. Heaton, E. A., Dohleman, F. G., Miguez, A. F., Juvik, J. A., Lozovaya, V., Widholm, J., et al. (2010). Miscanthus: a promising biomass crop. Advances in Botanical Research, 56, 75-137.

27. Zub, H. W., Arnoult, A., \& Brancourt-Hulmel, M. (2011). Key traits for biomass production identified in different Miscanthus species at two harvest dates. Biomass and Bioenergy, 35, 637-651.

28. Jeżowski, S., Głowacka, K., \& Kaczmarek, Z. (2011). Variation on biomass yield and morphological traits of energy grasses from the genus Miscanthus during the first years of crop establishment. Biomass and Bioenergy, 35, 814-821.

29. Xu, W. Z., Zhang, X. Q., Huang, L. K., Nie, G., \& Wang, J. P. (2013). Higher genetic diversity and gene flow in wild populations of Miscanthus sinensis in southwest China. Biochemical Systematics and Ecology, 48, 174-181.

30. Welsh, J., \& McClelland, M. (1990). Fingerprinting genomes using PCR with arbitrary primers. Nucleic Acids Research, 18, 7213-7218.

31. Williams, J. G. K., Kubelik, A. R., Livak, K. J., Rafalski, J. A., \& Tingey, S. V. (1990). DNA polymorphisms amplified by arbitrary primers are useful as genetic markers. Nucleic Acids Research, $18,6531-6535$.

32. Zietkiewicz, E., Rafalski, A., \& Labuda, D. (1994). Genome fingerprinting by simple sequence repeat (SSR)-anchored polymerase chain reaction amplification. Genomics, 20, 176-183.

33. Atienza, S. G., Satovic, Z., Petersen, K. K., Dolstra, O., \& Martín, A. (2002). Preliminary genetic linkage map of Miscanthus sinensis with RAPD markers. Theoretical and Applied Genetics (TAG), 105, 946-952.

34. Kim, J. K., An, G. H., Ahn, S. H., Moon, Y.-H., Cha, Y.-L., Bark, S.T., et al. (2012). Development of SCAR marker for simultaneous identification of Miscanthus sacchariflorus, M. sinensis and M. $\times$ giganteus. Bioprocess and Biosystems Engineering, 35, 55-59.

35. Qin, Y., Kabir, M. A., Wang, H. W., Kwon, Y. S., Yook, M. J., Kim, D. S., et al. (2013). Assessment of genetic diversity and relationships based on RAPD and AFLP analyses in Miscanthus genera landraces. The Canadian Journal of Plant Science, 93, $1-12$.

36. Zhang, Q. X., Shen, Y. K., Shao, R. X., Fang, J., He, Y. Q., Ren, J. X., et al. (2013). Genetic diversity of natural Miscanthus sinensis populations in China revealed by ISSR markers. Biochemical Systematics and Ecology, 48, 248-256.

37. Murray, M. G., \& Thompson, W. F. (1980). Rapid isolation of high molecular weight plant DNA. Nucleic Acids Research, 8, 4321-4326.

38. Galbraith, D. W. (1989). Analysis of higher plants by flow cytometry and cell sorting. International Review of Cytology, $116,165-228$

39. Ghislain, M., Zhang, D., Fajardo, D., Huamán, Z., \& Hijmans, R. J. (1999). Marker-assisted sampling of the cultivated Andean potato Solanum phureja collection using RAPD markers. Genetic Resources and Crop Evolution, 46, 547-555.

40. Nei, M., \& Li, W. H. (1979). Mathematical model for studying genetic variation in terms of restriction endonucleases. Proceeding of the National Academy of Science of the United States of America, 76, 5269-5273.

41. Gower, J. C. (1985). Measures of similarity, dissimilarity and distances. In S. Kotz, et al. (Eds.), Encyclopedia of statistical sciences (pp. 397-405). New York: Wiley.

42. Reif, J. C., Melchinger, A. E., \& Frisch, M. (2005). Genetical and mathematical properties of similarity and dissimilarity coefficients applied in plant breeding and seed bank management. Crop Science, 45, 1-7.

43. Gower, J. C. (1972). Measures of taxonomic distance and their analysis. In J. S. Weiner \& J. Huizinger (Eds.), The assessment of population affinities in man (pp. 1-24). Oxford: Clarendon Press.

44. Sneath, P. H. A., \& Sokal, R. R. (1973). Numerical taxonomy: the principles and practice of numerical classification. San Francisco: W. H. Freeman and Co.

45. Tessier, C., David, J., This, P., Boursiquot, J. M., \& Charrier, A. (1999). Optimization of the choice of molecular markers for 
varietal identification in Vitis vinifera L. Theoretical and Applied Genetics (TAG), 98, 171-177.

46. Archak, S., Gaikwad, A. B., Gautam, D., Rao, E. V. V. B., Swamy, K. R. M., \& Karihaloo, J. L. (2003). Comparative assessment of DNA fingerprinting techniques (RAPD, ISSR and AFLP) for genetic analysis of cashew (Anacardium occidentale L.) accessions of India. Genome, 46, 362-369.

47. Esselman, E. J., Jianqiang, L., Crawford, D. J., Windus, J. L., \& Wolfe, A. D. (1999). Clonal diversity in the rare Calamagrostis porteri ssp. insperata (Poaceae): comparative results for allozymes and random amplified polymorphic DNA (RAPD) and inter simple sequence repeat (ISSR) markers. Molecular Ecology, $8,443-451$.

48. Raina, S. N., Rani, V., Kojima, T., Ogihara, Y., Singh, K. P., \& Devarumath, R. M. (2001). RAPD and ISSR fingerprints as useful genetic markers for analysis of genetic diversity, varietal identification and phylogenetic relationships in peanut (Arachis hypogaea) cultivars and wild species. Genome, 44, 763-772.

49. Qian, W., Ge, S., \& Hong, D. Y. (2001). Genetic variation within and among populations of wild rice Oryza granulate from China detected by RAPD and ISSR markers. Theoretical and Applied Genetics (TAG), 102, 440-449.

50. Chowdhury, M. A., Vandenberg, B., \& Warkentin, T. (2002). Cultivar identification and genetic relationship among selected breeding lines and cultivars in chickpea (Cicer arietinum L.). Euphytica, 127, 317-325.

51. Fernández, M. E., Figueiras, A. M., \& Benito, C. (2002). The use of ISSR and RAPD markers for detecting DNA polymorphism, genotype identification and genetic diversity among barley cultivars with known origin. Theoretical and Applied Genetics (TAG), 104, 845-851.

52. Da Costa, M. L. M., Amorim, L. L. B., Onofre, A. V. C., De Melo, L. J. O. T., De Oliveira, M. B. M., De Carvalho, R., et al. (2011). Assessment of genetic diversity in contrasting sugarcane varieties using inter-simple sequence repeat (ISSR) markers. American Journal of Plant Sciences, 2, 425-432.

53. Thul, S. T., Darokar, M. P., Shasany, A. K., \& Khanuja, S. P. S. (2012). Molecular profiling for genetic variability in Capsicum species based on ISSR and RAPD markers. Molecular Biotechnology, 51, 137-147.
54. Awasthi, A. K., Nagaraja, G. M., Naik, G. V., Kanginakudru, S., Thangavelu, K., \& Nagaraju, J. (2004). Genetic diversity and relationships in mulberry (genus Morus) as revealed by RAPD and ISSR marker assays. BioMed Central, 5, 1-9.

55. Chae, W. B. (2012) Cytogenetics and genome structure in genus Miscanthus, a potential source of bioenergy feedstocks. Unpublished $\mathrm{PhD}$ thesis, University of Illinois at Urbana-Champaign, Illinois.

56. Chouvarine, P., Cooksey, A. M., McCarthy, F. M., Ray, D. A., Baldwin, B. S., Burgess, S. C., et al. (2012). Transcriptome-based differentiation of closely-related Miscanthus lines. PLOS One, 1, 1-8.

57. Zub, H. W., Rambaud, C., Béthencourt, L., \& Brancourt-Hulmel, M. (2012). Late emergence and rapid growth maximize the plant development of Miscanthus clones. BioEnergy Research, 5, 841-854.

58. Bossdorf, O., Auge, H., Lafuma, L., Rogers, W. E., Siemann, E., \& Prati, D. (2005). Phenotypic and genetic differentiation between native and introduced plant populations. Oecologia, 144, 1-11.

59. Nishiwaki, A., Mizuguti, A., Kuwabara, S., Toma, Y., Ishigaki, G., Miyashita, T., et al. (2011). Discovery of natural Miscanthus (Poaceae) triploid plants in sympatric populations of Miscanthus sacchariflorus and Miscanthus sinensis in southern Japan. The American Journal of Botany, 98, 154-159.

60. Dwiyanti, M. S., Rudolph, A., Swaminathan, K., Nishiwaki, A., Shimono, Y., Kuwabara, S., et al. (2013). Genetic Analysis of Putative Triploid Miscanthus Hybrids and Tetraploid M. sacchariflorus Collected from Sympatric Populations of Kushima, Japan. Bioenergy Research, 6, 486-493.

61. Quinn, L. D., Culley, T. M., \& Stewart, J. R. (2012). Genetic comparison of introduced and native populations of Miscanthus sinensis (Poaceae), a potential bioenergy crop. Grassland Science, 58, 101-111.

62. Farrell, A. D., Clifton-Brown, J. C., Lewandowski, I., \& Jones, M. B. (2006). Genotypic variation in cold tolerance influences the yield of Miscanthus. Annals of Applied Biology, 149, 337-345.

63. Stewart, J. R., Toma, Y., Fernandez, F. G., Nishiwaki, A., Yamada, T., \& Bollero, G. (2009). The ecology and agronomy of Miscanthus sinensis, a species important to bioenergy crop development, in its native range in Japan: a review. Global Change Biology Bioenergy, 1, 126-153. 